University of Nebraska - Lincoln

DigitalCommons@University of Nebraska - Lincoln

3-1-2017

\title{
Testing the Terminal Investment Hypothesis in California Oaks
}

Walter D. Koenig

Cornell Lab of Ornithology, Ithaca \& Hastings Natural History Reservation, Carmel Valley Cornell \& University, Ithaca, wdk4@cornell.edu

Johannes M.H. Knops

University of Nebraska-Lincoln, jknops@unl.edu

William J. Carmen

Carmen Ecological Consulting, Mill Valley

Mario B. Pesendorfer

Cornell Lab of Ornithology, Ithaca \& Hastings Natural History Reservation, Carmel Valley

Follow this and additional works at: https://digitalcommons.unl.edu/bioscifacpub

Part of the Biology Commons

Koenig, Walter D.; Knops, Johannes M.H.; Carmen, William J.; and Pesendorfer, Mario B., "Testing the Terminal Investment Hypothesis in California Oaks" (2017). Faculty Publications in the Biological Sciences. 797.

https://digitalcommons.unl.edu/bioscifacpub/797

This Article is brought to you for free and open access by the Papers in the Biological Sciences at DigitalCommons@University of Nebraska - Lincoln. It has been accepted for inclusion in Faculty Publications in the Biological Sciences by an authorized administrator of DigitalCommons@University of Nebraska - Lincoln. 


\title{
Testing the Terminal Investment Hypothesis in California Oaks
}

\author{
Walter D. Koenig, ${ }^{1,2,}$ Johannes M. H. Knops, ${ }^{3}$ William J. Carmen, ${ }^{4}$ and Mario B. Pesendorfer ${ }^{1}$ \\ 1. Cornell Lab of Ornithology, Ithaca, New York 14850; and Hastings Natural History Reservation, Carmel Valley, California 93924; \\ 2. Department of Neurobiology and Behavior, Cornell University, Ithaca, New York 14853; 3. School of Biological Sciences, University \\ of Nebraska, Lincoln, Nebraska 68588; 4. Carmen Ecological Consulting, Mill Valley, California 94941
}

Submitted September 6, 2016; Accepted December 7, 2016; Electronically published March 1, 2017

Online enhancements: appendix. Dryad data: http://dx.doi.org/10.5061/dryad.51ft1.

\begin{abstract}
AвSTRACT: The terminal investment hypothesis—-which proposes that reproductive investment should increase with age-related declines in reproductive value - has garnered support in a range of animal species but has not been previously examined in long-lived plants, such as trees. We tested this hypothesis by comparing relative acorn production and radial growth among 1,000+ mature individuals of eight species of California oaks (genus Quercus) followed for up to 37 years, during which time 70 trees died apparently natural deaths. We found no significant differences in the radial growth, acorn production, or index of reproductive effort, taking into consideration both growth and reproduction among dying trees relative to either conspecific trees at the same site that did not die or growth and reproduction from earlier years for the focal trees that did eventually die. Furthermore, we found no consistent tradeoff between growth and reproduction among trees that died, nor did dying trees significantly alter their relative investment in reproduction even as they underwent physical decline. Trees approaching the end of their lives are often in poor physical condition but do not appear to differentially invest more of their diminished resources in reproduction compared with healthy trees.
\end{abstract}

Keywords: demography, life history, oaks, senescence, terminal investment.

\section{Introduction}

Among the many contributions to evolutionary biology made by the late G. C. Williams is the hypothesis that individuals should shift more of their resources into reproduction as they approach the end of their lives (Williams 1966). Known as the terminal investment hypothesis (CluttonBrock 1984), it assumes that there are trade-offs between reproduction, growth, and survivorship and that the probability of survival decreases with age - that is, that organisms senesce. Given these assumptions, it follows that there is

\footnotetext{
* Corresponding author; e-mail: wdk4@cornell.edu. ORCIDs: Koenig, http://orcid.org/0000-0001-6207-1427; Knops, http://orcid .org/0000-0002-9647-9209; Pesendorfer, http://orcid.org/0000-0002-7994-7090.

Am. Nat. 2017. Vol. 189, pp. 564-569. (C) 2017 by The University of Chicago. 0003-0147/2017/18905-57237\$15.00. All rights reserved. DOI: $10.1086 / 691161$
}

likely to be a fitness advantage to invest more in reproduction as individuals approach the limits of their life span.

Thus far, support for the terminal investment hypothesis has been reported in many animals that have been examined, including species as diverse as burying beetles (Creighton et al. 2009), fishes (Bercovitch et al. 2009), birds (Velando et al. 2006), and primates (Hoffman et al. 2010), including humans (Tifferet and Kruger 2010). Several studies have not supported this hypothesis, however (Yoccoz et al. 2002), and there are few comparable studies for plants. Indeed, Hamilton (1966) suggested that actuarial senescence in plants may be negligible, a hypothesis that now has considerable support from subsequent studies (Baudisch et al. 2013; Caswell and Salguero-Gómez 2013). Nonetheless, there has been little work examining the pattern of reproductive senescence in plants, which is the relevant information for the terminal investment hypothesis. In one of the few studies of which we are aware, Shefferson and Roach (2013) found evidence countering this hypothesis in the shortlived iteroparous perennial Plantago lanceolata, where both size and reproduction decline with age. There appear to be no prior studies examining reproductive senescence or terminal investment in long-lived trees.

In contrast, there are many studies regarding the role of stress as indicated by growth rates and mortality of trees; these studies have typically found that growth is reduced before death (Waring 1987; Pederson 1998; Das et al. 2007). Given the possibility that this reduction is a consequence of a reallocation of resources to reproduction rather than physiological decline affecting both growth and reproduction, studies investigating the possibility that long-lived trees support the terminal investment hypothesis clearly warrant investigation.

Here we test the terminal investment hypothesis as part of a long-term study of reproduction and life-history strategies of California oaks (genus Quercus). We gathered data on acorn production on 1,067 individuals of eight species at a series of sites across the state over a period of 20 years. In addition, we obtained data on both acorn production and 
radial growth on 250 trees of five species at a site in central coastal California over an even longer time period. Over the course of the study, enough individuals died of apparently natural causes that we can now examine patterns of growth and reproduction just before death as a test of the hypothesis that the trees differentially invest in reproduction, as predicted by the terminal investment hypothesis.

Two complications of such a test are that oaks can live for hundreds of years and are typically mast fruiting, with reproduction varying greatly among both years and individuals (Kelly and Sork 2002; Koenig and Knops 2005). As such, testing for terminal investment requires a long-term study involving enough individuals that variability across years and among trees can be accommodated.

\section{Methods \\ Data}

Two related data sets were used for this analysis. The first was a sample of 250 mature trees of five species studied at Hastings Natural History Reservation in central coastal California since 1980 (Koenig et al. 1994b). These trees-for which we had data on both growth and reproductionwere used in analyses involving radial growth. The second data set, involving data on only acorn production, included 817 mature individuals of eight species from various sites across California, a complete list of which is provided in table A1 (tables A1-A3 are available online). Although some changes and additions were made throughout the course of the study, trees were generally subject to visual acorn counts each year between 1994 and 2016.

Acorn production was estimated by means of visual surveys conducted each autumn. Surveys consisted of two observers counting as many acorns as they could in $15 \mathrm{~s}$; values were then added and ln-transformed in order to reduce skew in the data (Koenig et al. 1994a), to better match prior analyses and because generalized linear mixed models in which untransformed acorn count data were used with a Poisson error distribution exhibited poor convergence. To measure radial growth, trees at Hastings were fitted with dendrometers (Cattelino et al. 1986) in 1993, and radial growth was measured annually thereafter. The relationship between radial growth as measured by mean circumference increment and tree size (diameter at breast height $[\mathrm{DBH}]$ ) was not significantly size dependent (mixed-effects model with species included as a random factor; mean growth increment $=0.013( \pm 0.011 \mathrm{SE}) \times \mathrm{DBH} ; t=1.17, N=$ 238 trees, $P=.24$ ). Thus, we used mean annual circumference increment as measured by the dendrometers as our index of growth investment.

Trees were visited each year in September, when we conducted the acorn survey and assessed whether individuals were dead or alive on the basis of the presence of new or green leaves. In all cases, trees included in the died category either fell or remained standing but exhibited no new growth; trees that were killed by fire and four individuals that may have been cut were excluded from the analyses. For each tree that died (the focal tree), we compiled data on acorn production and (when available) radial growth for the years before death along with parallel data for the mean values for all trees of the same species at the same site during the same years (comparison trees). Results were unchanged using the two trees (one the same size or larger; the other the same size or smaller) of the same species at the same site that were closest in size to the focal tree as comparison trees to control for any sizedependent scaling of reproduction. We then recorded data for the focal tree along with the mean acorn crop and mean radial growth for the comparison trees. Data were analyzed using R 3.3.1 (R Development Core Team 2016).

\section{Analyses}

Two sets of analyses were conducted. The first set compared the population of trees that died (focal trees) to trees of the same species at the same site that lived (comparison trees). Two tests were conducted. The first involved reverse-age analyses in which trees were standardized on the basis of their year of death, similar to analyses performed previously by Martin and Festa-Bianchet (2011) on bighorn sheep (Ovis canadensis), Hammers et al. (2012) on Seychelles warblers (Acrocephalus sechellensis), and Shefferson and Roach (2013) on Plantago. Analyses involved linear mixed-effects models (procedure lmer in the lme4 package; Bates et al. 2015). For each focal tree and each set of comparison trees, we compiled data on the acorn crop (ln-transformed) and (when available) radial growth as dependent variables and size $(\mathrm{DBH})$, year relative to time of death of the focal tree, whether the tree died (i.e., whether it was a focal tree or the comparison trees), and the interaction between these latter two variables as fixed effects. Year of death and individual within species within locality (individual within species for the analysis of growth, since these data were from only a single site) were included as random effects to account for temporal and spatial variation in conditions. Since we were interested in the differences between trees that died and trees that survived, the relevant results consisted of the interaction terms between year relative to time of death and whether the tree died (the focal tree vs. comparison trees). We analyzed and plotted the effect sizes for the interaction terms for the 6 years just before death (year -5 to year 0 ) compared with the average of the values for the prior 5 years (year -10 to year -6$)$.

The second test that compared trees that died with those that lived involved standardizing both the acorn crop (lntransformed) and radial growth of trees to between 0 to 1 
on the basis of their maximum and minimum values over the complete length of time for which we had data. We then calculated an index of reproductive investment - defined as the standardized acorn crop divided by the sum of the standardized acorn crop plus standardized radial growth-over the last 6 years of life (year -5 to year 0 ). The index of reproductive investment for each focal tree was then compared with the mean of all trees that did not die of the same species during the same years. (All data for this analysis were from the Hastings Natural History Reservation site, where radial growth was measured.)

We conducted a second set of analyses examining the hypothesis that reduced growth may be a cost of increased investment in acorn production within the same tree rather than on a population level. First, we performed Spearman rank correlations between acorn production and radial growth of trees that died over the 6 years from year -5 to year 0 , and we report the mean correlation coefficient and the proportion of trees for which the correlation was negative, as predicted by this hypothesis. (Results were unchanged using data going back as far as year -10 before death.) This analysis - testing for a potential trade-off between growth and reproduction-was similar to analyses we have performed previously (Knops et al. 2007), except that here we restricted our analyses to the years just before death, thus testing the relationship between growth and reproduction during the last years of a tree's life.

Finally, we tested the possibility that dying trees may invest relatively more of their reserves into reproduction compared with radial growth, even if their relative investment in both growth and reproduction decrease. We averaged the index of reproductive investment as defined above for years
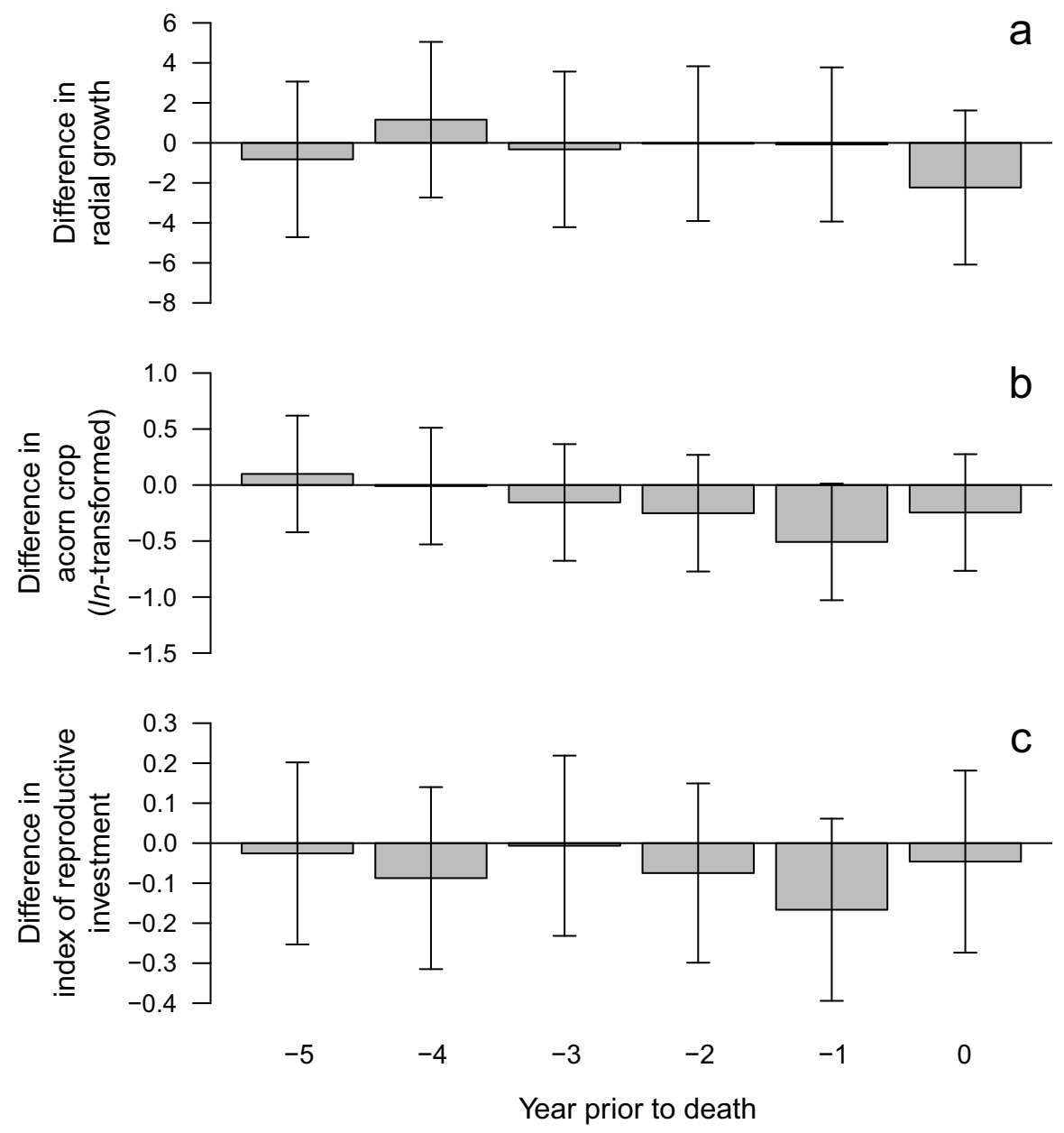

Figure 1: Mean ( $\pm 95 \%$ confidence interval) difference in absolute radial growth $(a)$, acorn production (ln-transformed; $b$ ), and index of reproductive effort $(c)$ for trees that died compared with trees of the same species and site that lived in the years before death. Values estimated by the effect size of the interaction terms between years before death and whether the tree died derived from mixed-effects models. Values are plotted for the 6 years before death (year -5 to year 0 ). For further details of the analyses, see table A3, available online. 
-10 through -6 for each tree that died and compared this value with the index of reproductive investment for the same trees for each of years -5 to 0 , using paired Wilcoxon twosample tests. We then tested for a trend in values over the last 6 years of life with a Spearman rank correlation.

\section{Results}

During the study, a total of 70 trees died for reasons that were apparently unrelated to fire or other anthropogenic causes (table A2). Of the trees that died, 23 were from Hastings; 17 of these provided data on both radial growth and acorn production.

Compared with the mean for the prior 5 years, both radial growth and acorn production were smaller among trees that died compared with those that lived for the last 6 years of life, with one exception (year -4 for radial growth; year -5 for acorn production); none of the differences was significant, however (fig. $1 a, 1 b$ ). Comparing the index of reproductive investment by trees that died to the mean of trees that lived, the index of investment was lower among trees that died in all cases but was again not significant for any of the years (fig. 1c). Complete details regarding these analyses are provided in table A3.

Of the 15 trees for which we were able to calculate correlations between growth and reproduction during the last 6 years of their lives, nine were positive and six were negative. Overall, the mean \pm SD Spearman rank correlation coefficient was $0.21 \pm 0.56$.

Seventeen trees provided data for estimating the index of reproductive effort during the last years of their lives; nine of these trees had data for all years we analyzed (year -5 to year 0 along with a mean for years -10 to -6$)$. Compared with the mean value of the index for years -10 to -6 , there were no significant differences for any of years -5 to 0 (six pairwise tests; all $P \geq .25$; fig. $2 a$ ). There was also no significant trend in the index including either all trees $\left(r_{\mathrm{s}}=0.002, P=.99\right.$; fig. $\left.2 b\right)$ or only the nine trees with data for all years $\left(r_{\mathrm{s}}=0.36, P=.42\right)$.

\section{Discussion}

Since it was first proposed 50 years ago, the terminal investment hypothesis has received considerable - although by no

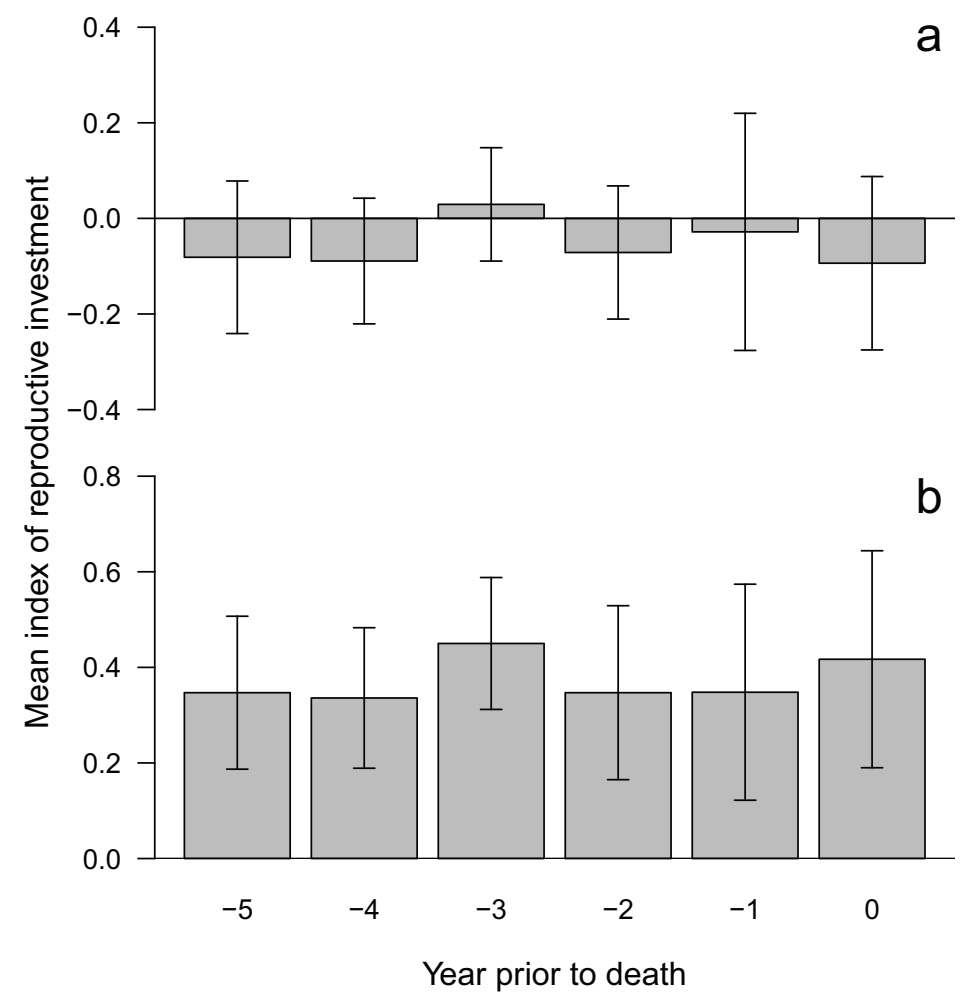

Figure 2: $a$, Mean $( \pm 95 \%$ confidence interval $[\mathrm{CI}])$ difference in the index of reproductive effort for the 6 years before death (year -5 to year 0 ) compared with the mean of the index for the same trees over years -10 to $-6 . b$, Mean $( \pm 95 \% \mathrm{CI})$ index of reproductive effort for the 6 years before death. 
means universal (Yoccoz et al. 2002) — support in animals ranging from insects to humans. However, we know of only one prior study investigating this hypothesis in iteroparous plants (Shefferson and Roach 2013). Indeed, the only scientific reference to this phenomenon in trees of which we are aware is in Crawley and Long's (1995, p. 692) article on Quercus robur, in which they reported that "acorn production increased significantly with the degree of stag-headedness . . . consistent with forester's folk lore that dying trees increase their reproductive output." Beyond this, terminal investment bears some similarities to the increased flowering and fruit production that often accompanies the girdling of trees, a procedure than typically results in death within several years (Noel 1970). It differs, however, in that the effects of girdling on productivity are due to interference with normal water transport and nutrient translocation, whereas terminal investment-if it exists - is presumably an evolved capacity of individuals that are senescing naturally.

Prior studies indicate that trees approaching the end of their lives typically exhibit inferior growth indicative of environmental stresses that are often exhibited during drought or other stressful periods (Pederson 1998, 1999). Other changes in allocation that have been found in trees undergoing stress include reductions in canopy growth, photosynthetic activity, and storage reserves (Waring 1987) and, in the case of Acer rufinerve, a shift in resources toward female flowers (Nanami et al. 2004) — a change that potentially is in accord with the terminal investment hypothesis.

Here we found no significant differences in growth, reproduction, or an index of reproductive investment that considered both reproduction and growth in California oaks during the last 6 years of their lives compared with either conspecific trees at the same site (fig. 1) or to growth and reproduction by the same trees during prior years (fig. $2 a$ ). Differences were, however, generally in the direction of trees investing less in reproduction during the years before their demise rather than more, thus countering the likelihood that significant support for terminal investment would be detected with additional data.

The terminal investment hypothesis is predicated on a trade-off between growth and reproduction. Such a tradeoff is an assumption of several hypotheses of aging, including antagonistic pleiotropy (Williams 1957) and the disposable soma theory (Kirkwood 1977), but not of, for example, the mutation accumulation hypothesis (Medawar 1952). Such a trade-off has often not been found in prior studies of trees (Sork et al. 1993; Crawley and Long 1995), nor was it evident in our data either here or in prior analyses of oaks at this site (Knops et al. 2007). Together, these results counter the hypothesis that oaks shift resources into reproduction in response to conditions potentially culminating in their demise.
This conclusion is based both on a relatively small sample of trees and on data taken during the last several years of life. Many oak species live hundreds of years, and death may be a decades-long phenomenon (Pederson 1998). It is therefore possible that oaks and other long-lived trees shift resources into reproduction many years before they finally die but still in response to stresses that may eventually kill them. Testing this possibility will clearly be a challenge, given the timescales potentially involved. In the short-term, however, our results do not support the hypothesis that oaks suffering from stress and thus more likely to die differentially shift resources into reproduction, as proposed by the terminal investment hypothesis.

\section{Acknowledgments}

We thank M. Crawley and L. Hadj-Chikh for discussion, W. Hochachka for statistical advice, and the reviewers for their comments. The study was supported by the National Science Foundation (most recently DEB-1256394 to W.D.K.) and the Integrated Hardwoods Range Management Program (University of California).

\section{Literature Cited}

Bates, D., M. Mächler, B. Bolker, and S. Walker. 2015. Fitting linear mixed-effects models using lme4. Iournal of Statistical Software 67: $1-48$.

Baudisch, A., R. Salguero-Gómez, O. R. Jones, T. Wrycza, C. MbeauAche, M. Franco, and F. Colchero. 2013. The pace and shape of senescence in angiosperms. Journal of Ecology 101:596-606.

Bercovitch, F. B., C. P. Loomis, and R. G. Rieches. 2009. Age-specific changes in reproductive effort and terminal investment in female Nile lechwe. Journal of Mammalogy 90:40-46.

Caswell, H., and R. Salguero-Gómez. 2013. Age, stage and senescence in plants. Journal of Ecology 101:585-595.

Cattelino, P. J., C. A. Becker, and L. G. Fuller. 1986. Construction and installation of homemade dendrometer bands. Northern Journal of Applied Forestry 3:73-75.

Clutton-Brock, T. H. 1984. Reproductive effort and terminal investment in iteroparous animals. American Naturalist 123:212-229.

Crawley, M. J., and C. R. Long. 1995. Alternate bearing, predator satiation and seedling recruitment in Quercus robur L. Journal of Ecology 83:683-696.

Creighton, J. C., N. D. Heflin, and M. C. Belk. 2009. Cost of reproduction, resource quality, and terminal investment in a burying beetle. American Naturalist 174:673-684.

Das, A. J., J. J. Battles, N. L. Stephenson, and P. J. van Mantgem. 2007. The relationship between tree growth patterns and likelihood of mortality: a study of two tree species in the Sierra Nevada. Canadian Journal of Forest Research 37:580-597.

Hamilton, W. D. 1966. The moulding of senescence by natural selection. Journal of Theoretical Biology 12:12-45.

Hammers, M., D. S. Richardson, T. Burke, and J. Komdeur. 2012. Age-dependent terminal declines in reproductive output in a wild bird. PLoS One 7:e40413. 
Hoffman, C. L., J. P. Higham, A. Mas-Rivera, J. E. Ayala, and D. Maestripieri. 2010. Terminal investment and senescence in rhesus macaques (Macaca mulatta) on Cayo Santiago. Behavioral Ecology 21: 972-978.

Kelly, D., and V. L. Sork. 2002. Mast seeding in perennial plants: why, how, where? Annual Review of Ecology and Systematics 33:427447.

Kirkwood, T. B. L. 1977. Evolution of ageing. Nature 270:301-304.

Knops, J. M. H., W. D. Koenig, and W. J. Carmen. 2007. Negative correlation does not imply a tradeoff between growth and reproduction in California oaks. Proceedings of the National Academv of Sciences of the USA 104:16982-16985.

Koenig, W. D., and J. M. H. Knops. 2005. The mystery of masting in trees. American Scientist 93:340-347.

Koenig, W. D., J. M. H. Knops, W. J. Carmen, M. T. Stanback, and R. L. Mumme. 1994a. Estimating acorn crops using visual surveys. Canadian Journal of Forest Research 24:2105-2112.

Koenig, W. D., R. L. Mumme, W. J. Carmen, and M. T. Stanback. 1994b. Acorn production by oaks in central coastal California: variation within and among years. Ecology 75:99-109.

Martin, J. G. A., and M. Festa-Bianchet. 2011. Age-independent and age-dependent decreases in reproduction of females. Ecology Letters 14:576-581.

Medawar, P. B. 1952. An unsolved problem in biology. H. K. Lewis, London.

Nanami, S., H. Kawaguchi, and T. Yamakura. 2004. Sex change towards female in dying Acer rufinerve trees. Annals of Botany 93: 733-740.

Noel, A. R. A. 1970. The girdled tree. Botanical Review 36:162-195.

Pederson, B. S. 1998. The role of stress in the mortality of Midwestern oaks as indicated by growth prior to death. Ecology 79:79-93.
1999. The mortality of Midwestern overstory oaks as a bioindicator of environmental stress. Ecological Applications 9:10171027.

R Development Core Team. 2016. R: a language and environment for statistical computing. R Foundation for Statistical Computing, Vienna. http://www.R-project.org.

Shefferson, R. P., and D. A. Roach. 2013. Longitudinal analysis in Plantago: strength of selection and reverse age analysis reveal ageindeterminate senescence. Journal of Ecology 101:577-584.

Sork, V. L., J. Bramble, and O. Sexton. 1993. Ecology of mast-fruiting in three species of North American deciduous oaks. Ecology 74:528541.

Tifferet, S., and D. J. Kruger. 2010. The terminal investment hypothesis and age-related differences in female preference for dads vs. cads. Letters on Evolutionary Behavioral Science 1:27-30.

Velando, A., H. Drummond, and R. Torres. 2006. Senescent birds redouble reproductive effort when ill: confirmation of the terminal investment hypothesis. Proceedings of the Roval Societv B 273:14431448 .

Waring, R. H. 1987. Characteristics of trees predisposed to die. BioScience 37:569-574.

Williams, G. C. 1957. Pleiotropy, natural selection, and the evolution of senescence. Evolution 11:398-411.

1966. Adaptation and natural selection: a critique of some current evolutionary thought. Princeton University Press, Princeton, NJ.

Yoccoz, N. G., A. Mysterud, R. Langvatn, and N. C. Stenseth. 2002. Age- and density-dependent reproductive effort in male red deer. Proceedings of the Roval Societv B 269:1523-1528.

Natural History Editor: Mark A. McPeek

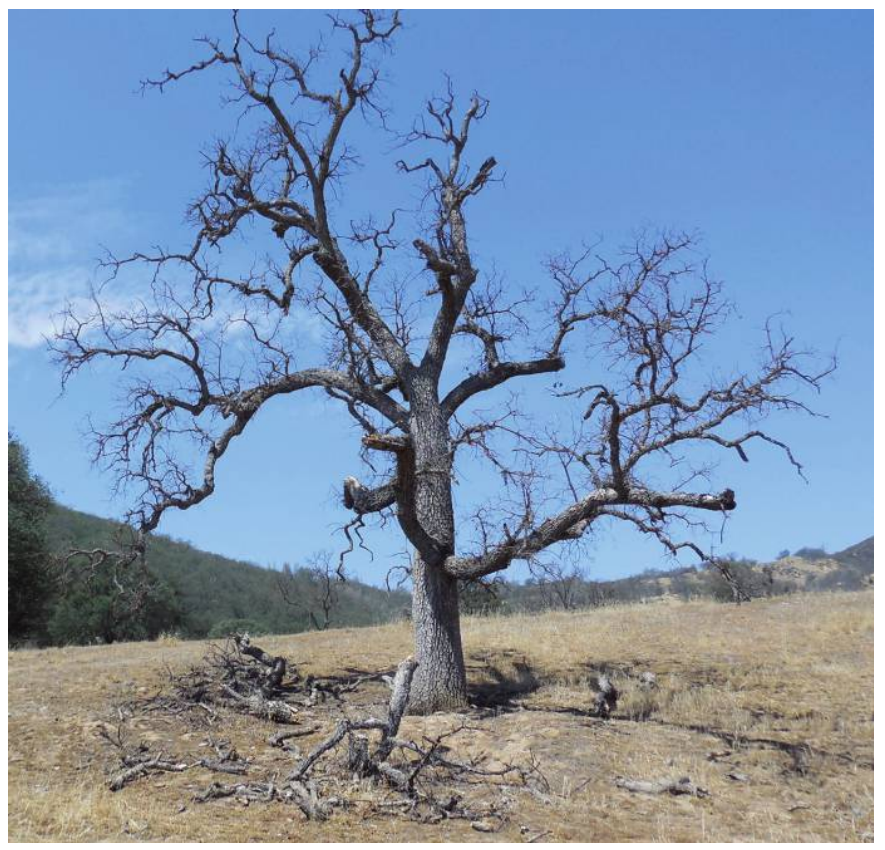

Valley oak (Quercus lobata) from central coastal California, one of the 70 trees that died of natural causes studied to test whether oaks invest more in producing acorns than expected in the years before their demise. Photo credit: Walter D. Koenig. 
Appendix from W. D. Koenig et al., "Testing the Terminal Investment Hypothesis in California Oaks"

(Am. Nat., vol. 189, no. 5, p. 564)

Details of Sampling Sites, Trees That Died, and Linear Mixed-Effects Models 


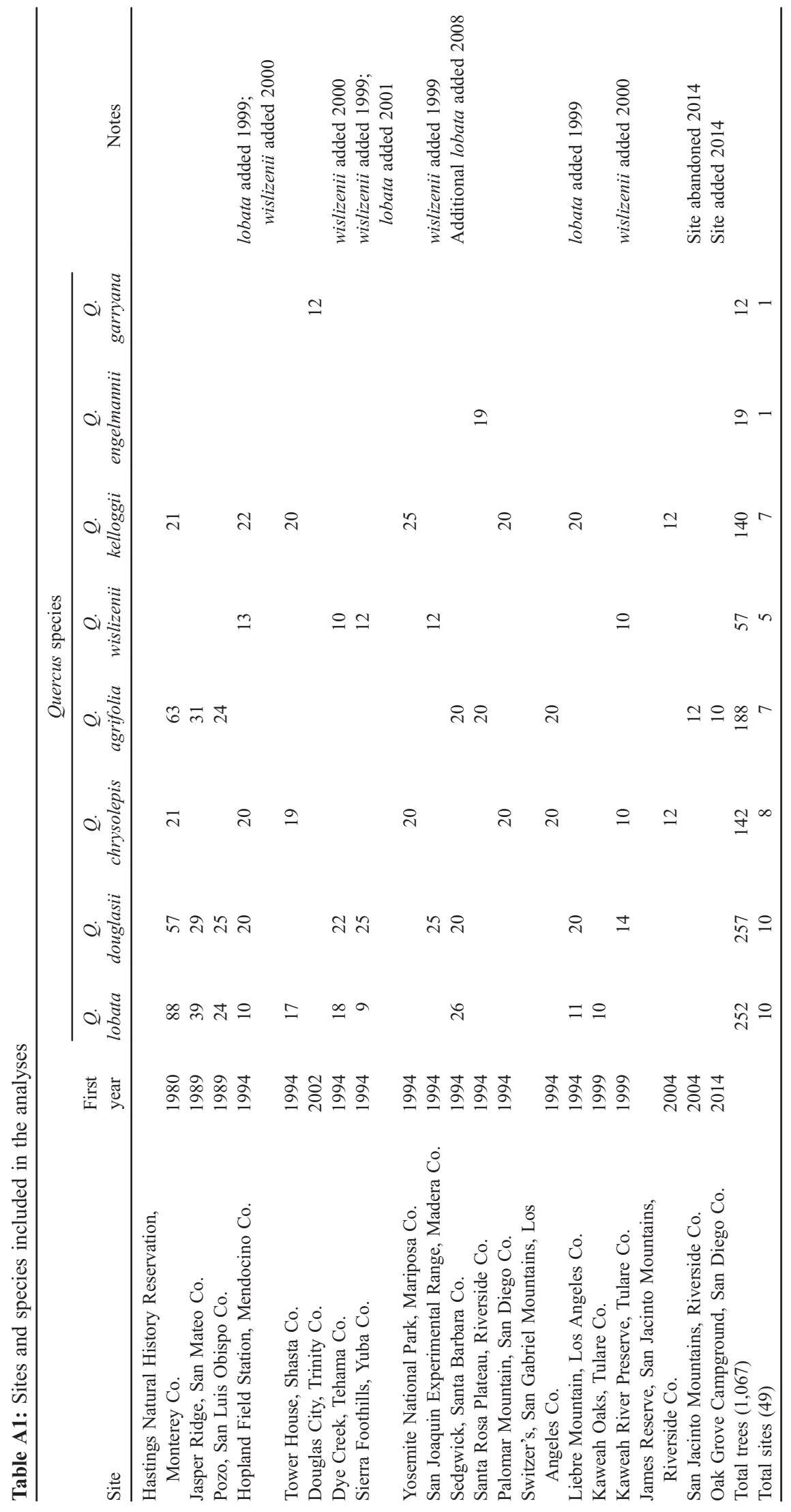


Appendix from W. D. Koenig et al., Testing the Terminal Investment Hypothesis in California Oaks

Table A2: Species and locality of trees that died during the study

\begin{tabular}{|c|c|c|c|c|c|c|c|c|}
\hline \multirow[b]{2}{*}{ Site } & \multicolumn{8}{|c|}{ Quercus species } \\
\hline & $\begin{array}{c}Q . \\
\text { lobata }\end{array}$ & $\begin{array}{c}Q . \\
\text { douglasii }\end{array}$ & $\begin{array}{c}Q . \\
\text { chrysolepis }\end{array}$ & $\underset{\text { agrifolia }}{Q .}$ & $\underset{\text { wislizenii }}{Q .}$ & $\underset{\text { kelloggii }}{Q .}$ & $\begin{array}{c}Q . \\
\text { engelmannii }\end{array}$ & $\underset{\text { garryana }}{Q .}$ \\
\hline $\begin{array}{l}\text { Hastings Natural History Reservation, } \\
\text { Monterey Co. }\end{array}$ & 5 & 2 & 1 & 5 & & 10 & & \\
\hline Jasper Ridge, San Mateo Co. & 1 & 1 & & 1 & & & & \\
\hline Pozo, San Luis Obispo Co. & 2 & 1 & & 3 & & & & \\
\hline Hopland Field Station, Mendocino Co. & 0 & 1 & 0 & & 1 & 0 & & \\
\hline Tower House, Shasta Co. & 1 & & 0 & & & 3 & & \\
\hline Douglas City, Trinity Co. & & & & & & & & 0 \\
\hline Dye Creek, Tehama Co. & 1 & 1 & & & 3 & & & \\
\hline Sierra Foothills, Yuba Co. & 2 & 0 & & & 0 & & & \\
\hline Yosemite National Park, Mariposa Co. & & & 0 & & & 0 & & \\
\hline $\begin{array}{l}\text { San Joaquin Experimental Range, } \\
\text { Madera Co. }\end{array}$ & & 0 & & & 2 & & & \\
\hline Sedgwick Reserve, Santa Barbara Co. & 0 & 0 & & 0 & & & & \\
\hline Santa Rosa Plateau, Riverside Co. & & & & 4 & & & 3 & \\
\hline Palomar Mountain, San Diego Co. & & & 0 & & & 1 & & \\
\hline Switzer's, San Gabriel Mountains, & & & & & & & & \\
\hline $\begin{array}{l}\text { Los Angeles Co. } \\
\text { Liebre Mountain. Los Angeles Co }\end{array}$ & & & 1 & 0 & & & & \\
\hline $\begin{array}{l}\text { Liebre Mountain, Los Angeles Co. } \\
\text { Kaweah Oaks, Tulare Co }\end{array}$ & 4 & 1 & & & & 3 & & \\
\hline & 5 & & & & & & & \\
\hline Kaweah River Preserve, Tulare Co. & & 0 & 0 & & 1 & & & \\
\hline $\begin{array}{l}\text { James Reserve, San Jacinto Mountains, } \\
\text { Riverside Co. }\end{array}$ & & & 0 & & & 0 & & \\
\hline San Jacinto Mountains, Riverside Co. & & & & 0 & & & & \\
\hline Oak Grove Campground, San Diego Co. & & & & 0 & & & & \\
\hline Total mortality & 21 & 7 & 2 & 13 & 7 & 17 & 3 & 0 \\
\hline
\end{tabular}


Table A3: Results of linear mixed-effects models (lmer) of radial growth, reproduction (acorn crop, ln-transformed), and index of reproductive investment on size (diameter at breast height), whether trees died, years before death (year -5 to year 0 ), and interaction between the latter two variables

\begin{tabular}{|c|c|c|c|}
\hline Fixed factor & Effect size $\pm \mathrm{SE}$ & $t$ & $P$ \\
\hline \multicolumn{4}{|l|}{ Radial growth $(N=17$ trees $)$ : } \\
\hline Died & $-2.24 \pm 1.46$ & -1.54 & .13 \\
\hline Diameter at breast height & $-.004 \pm .014$ & -.29 & .77 \\
\hline Year -5 & $.48 \pm 1.56$ & .31 & .76 \\
\hline Year -4 & $.95 \pm 1.57$ & .60 & .55 \\
\hline Year -3 & $1.88 \pm 1.59$ & 1.18 & .24 \\
\hline Year -2 & $.20 \pm 1.59$ & .13 & .90 \\
\hline Year -1 & $.03 \pm 1.60$ & .02 & .99 \\
\hline Year 0 & $.30 \pm 1.60$ & .19 & .85 \\
\hline Died $\times$ year -5 & $-.82 \pm 2.05$ & -.40 & .69 \\
\hline Died $\times$ year -4 & $1.16 \pm 2.05$ & .57 & .57 \\
\hline Died $\times$ year -3 & $-.32 \pm 2.05$ & -.16 & .88 \\
\hline Died $\times$ year -2 & $-.04 \pm 2.04$ & -.02 & .99 \\
\hline Died $\times$ year -1 & $-.08 \pm 2.03$ & -.04 & .97 \\
\hline Died $\times$ year 0 & $-2.23 \pm 2.03$ & -1.10 & .27 \\
\hline \multicolumn{4}{|l|}{ Acorn crop $(N=70$ trees $)$ : } \\
\hline Died & $-.16 \pm .19$ & -.86 & .39 \\
\hline Diameter at breast height & $.003 \pm .002$ & 1.54 & .12 \\
\hline Year -5 & $-.53 \pm .20$ & -2.65 & .008 \\
\hline Year -4 & $-.20 \pm .20$ & -1.02 & .31 \\
\hline Year -3 & $-.18 \pm .20$ & -.91 & .36 \\
\hline Year -2 & $-.30 \pm .20$ & -1.47 & .14 \\
\hline Year -1 & $-.18 \pm .20$ & -.89 & .37 \\
\hline Year 0 & $-.36 \pm .21$ & -1.76 & .08 \\
\hline Died $\times$ year -5 & $.10 \pm .27$ & .37 & .71 \\
\hline Died $\times$ year -4 & $-.01 \pm .27$ & -.04 & .97 \\
\hline Died $\times$ year -3 & $-.16 \pm .27$ & -.59 & .56 \\
\hline Died $\times$ year -2 & $-.25 \pm .27$ & -.95 & .34 \\
\hline Died $\times$ year -1 & $-.51 \pm .27$ & -1.91 & .06 \\
\hline Died $\times$ year 0 & $-.25 \pm .27$ & -.92 & .36 \\
\hline \multicolumn{4}{|c|}{ Index of reproductive investment ( $N=17$ trees): } \\
\hline Died & $-.039 \pm .082$ & -.48 & .63 \\
\hline Diameter at breast height & $.0020 \pm .0008$ & 2.44 & .02 \\
\hline Year -5 & $-.044 \pm .083$ & -.54 & .59 \\
\hline Year -4 & $.011 \pm .008$ & .13 & .31 \\
\hline Year -3 & $.048 \pm .084$ & .57 & .57 \\
\hline Year -2 & $-.016 \pm .083$ & -.19 & .85 \\
\hline Year -1 & $.048 \pm .082$ & .58 & .56 \\
\hline Year 0 & $-.033 \pm .082$ & .40 & .69 \\
\hline Died $\times$ year -5 & $-.026 \pm .116$ & -.22 & .83 \\
\hline Died $\times$ year -4 & $-.087 \pm .116$ & -.75 & .45 \\
\hline Died $\times$ year -3 & $-.006 \pm .115$ & -.06 & .96 \\
\hline Died $\times$ year -2 & $-.075 \pm .114$ & -.65 & .51 \\
\hline Died $\times$ year -1 & $-.166 \pm .116$ & -1.43 & .15 \\
\hline Died $\times$ year 0 & $-.046 \pm .116$ & -.40 & .69 \\
\hline
\end{tabular}

Note: For radial growth, year of death and individual within species within locality were included as random effects; for acorn crop and index of reproductive investment, year of death and individual within species were random effects. Values are relative to the mean of years -10 to -6 . Interactions - representing the differences in the effect sizes for trees that died versus those that did not - are plotted in figure 1. 